American Journal of Applied Sciences 9 (4): 557-562, 2012

ISSN 1546-9239

(C) 2012 Science Publications

\title{
Attitude towards Community Building in Association of Southeast Asian Nations: A Public Opinion Survey
}

\author{
${ }^{1}$ Ravichandran Moorthy and ${ }^{2}$ Guido Benny \\ ${ }^{1}$ School of History, Politics and Strategy, Faculty of Social Sciences and Humanities, \\ University Kebangsaan Malaysia, 43000 Bangi, Selangor, Malaysia \\ ${ }^{2}$ Department of Administrative Sciences, University of Indonesia (UI), Indonesia
}

\begin{abstract}
Problem statement: The Association of Southeast Asian Nations (ASEAN) envisioned an integrated regional community by the year 2015, following the European Union model. However, unlike the European Community which was formed after years of discussion at different levels of society, institutions and government, ASEAN was rather quick to conceptualize this initiative, without seeking the feedbacks for the public. Consequently, ASEAN Community initiative has been criticized for being elitist in its policy formulation process and for the lack of public opinions regarding this policy. The study examines how people in three ASEAN countries (Indonesia, Malaysia and Singapore) view the concept of community building, especially from the perspective of the obstacles that this initiative is perceived to encounter in its formation. Approach: The study employs public opinion surveys to gather feedback from respondents regarding their opinion of the obstacles towards the establishment of the ASEAN community by the year 2015. The surveys conducted in eleven cities in three ASEAN countries, namely Indonesia (Jakarta, Makassar, Medan, Surabaya and Pontianak), Malaysia (Kuala Lumpur, Penang, Melaka, Johor Bahru and Kota Kinabalu) and Singapore. The surveys involved 1256 respondents- 551 from Indonesia, 451 from Malaysia and 294 from Singapore. Results: The study reveals several findings; firstly the low levels of education in several ASEAN countries have been cited as the main factor that hinders regional integration; secondly there has been a lack of initiative to engage the public regarding their opinions on regional integration and thirdly, issues such as lack of economic competitiveness, dependency on develop countries, socio-economic disparity, differences in legal and political systems and technological divide have scored high agreements among respondents-as contributory factors that would possibly slow down regional integration initiatives. Conclusion: The study concludes that ASEAN has remained elitist, with least amount of public participation. As such, it requires legitimization from the population which the regional integration wishes to serve.
\end{abstract}

Key words: Public perception survey, ASEAN community, ASEAN integration, regionalization, regionalism, surveys conducted, European Community

\section{INTRODUCTION}

In 2003, the Bali Concord II has initiated the path for the Association of Southeast Asian Nations (ASEAN) to engage in efforts to forge regional integration among its members and undertake the project to build an integrated regional community by the year 2015 Declaration of Bali Concord II, 2003. ASEAN envisaged to build a community which is broad minded; living peacefully, steady and prosperous; bounded together in a partnership and in a dynamic development in a caring community. The community building initiative is to be supported by ASEAN's three pillars-the ASEAN Security Community, the ASEAN Economic Community and the ASEAN Socio-cultural Community. It is hoped that these three pillars will strengthen regional integration initiatives in the midst of regional and global challenges. It has been generally noted that the ASEAN Community initiative has been based on the European Union (EU) model of establishing the European Community. Nevertheless, ASEAN's initiative towards regional integration seems to have taken a different direction, as compared to the EU. The EU started off as a political and economic union of 27 European countries. Its roots can be traced from the European Coal and Steel Community and the

Corresponding Author: Ravichandran Moorthy, School of History, Politics and Strategy, Faculty of Social Sciences and Humanities, University Kebangsaan Malaysia, 43000 Bangi, Selangor, Malaysia Tel: +603-89215825

Fax: +603-89213290 
European Economic Community as early as 1958. The EU came into being after years of consultation at different levels of society, institutions and government, where public opinion surveys were (and still are) used to judge public reaction on a variety of issues concerning this regional organization.

In contrast, ASEAN Community initiative was conceptualized drafted and began to operationalize within limited time frame. In fact, compared to the EU, the 2015 target for ASEAN integration appeared to be too ambitious. ASEAN policy makers and diplomats have been accused for hastily pushing through this initiative, especially when a majority of its over 584 million population remained almost oblivious of such an initiative. To this date, there were no structured public opinion surveys conducted by ASEAN countries to gauge the level of acceptance of ASEAN Community. ASEAN policy makers have been criticized for their elitist high-handedness and lackadaisical attitude in soliciting public opinions. Compared to the EU, ASEAN lacks one of the most fundamental components that have brought about the success of other similar regional integration- which is the involvement of the general public. The public should be one of the key actors in the process of regional integration and policy makers should use public opinions and feedbacks in policy formulations. Failure to do so, some have argued, will render the whole initiative futile. In fact major theories of regional integration, namely the transactionalist, neofunctionalist and democratic theories have mutually advocated public opinions as integral part of the regional integration process-the success of such initiative may very well depend on the public support (Chong, 2008). The main objective of this article is to examine the obstacles for the establishment of the ASEAN community as perceived by the public in three ASEAN countries. This study shows that public opinions have not been given enough attention during the conceptualizing process of the ASEAN community. The study argues that regional integration can claims legitimacy only through public feedbacks and support. Without it, the initiative may possibly run the risk of being redundant in future.

\section{MATERIALS AND METHODS}

The study uses public opinion surveys conducted in 11 cities in three ASEAN countries, namely Indonesia (Jakarta, Makassar, Medan, Surabaya and Pontianak), Malaysia (Kuala Lumpur, Penang, Melaka, Johor Bahru and Kota Kinabalu) and Singapore. Empirical data were solicited through several structured close-ended and open-ended questions in three languages (Bahasa Indonesia, Bahasa Malaysia and English), involving a total of 1256 respondents; 551 from Indonesia, 451 from Malaysia and 294 from Singapore. The surveys solicit feedbacks from respondents residing in these cities on their opinion regarding the obstacles towards the establishment of the ASEAN community by 2015 .

\section{RESULTS}

The survey posted 10 suggested obstacles for the establishment of the ASEAN Community by the year 2015. From this list, the respondents were asked to evaluate the items based on three options-definitely, possibly or definitely not. The feedback from the survey is shown in Table 1.

The definately and possibly options (in Table 1) have been grouped together to show the total percentage of agreements solicited from the respondents. Based on the ranking order, item 1 (disparity in levels of education) registered $92 \%$ agreement. Items 2-6, also registered high agreement rate in the range between $82-88 \%$. Items 7 and 8 registered $77 \%$ agreement, while items 9 and 10 registered 64 and $60 \%$ respectively. There were no items that registered below $50 \%$ agreement responses. These figures suggest that there have been overwhelming agreement among the respondents that ASEAN community building initiatives will face the listed obstacles.

\section{DISCUSSION}

Eight items that have scored significant agreements from respondents (as showned in Table 1) will be analyzed and discussed.

Levels of education: A substantial majority of respondents have pointed out that low level of education, unequally access and distribution of educational opportunities (Item I, Table 1) in many ASEAN countries will pose major challenge to the ASEAN community building initiative. Some $91 \%$ of Malaysians, $92 \%$ of Indonesians and $92 \%$ of Singaporeans shared similar perception-that the lack of education is the most difficult obstacle for ASEAN integration. The high percentage agreement for this item is perhaps due to the knowledge that several ASEAN countries, namely Cambodia, Laos, Myanmar and Vietnam (the CLVM countries) have high level of illiteracy. For example the literacy rate in Cambodia and Laos are among the lowest in the region, with only 76.32 and $72.70 \%$ in each respective country Education Statistics, 2010. 
Am. J. Applied Sci., 9 (4): 557-562, 2012

Table 1: Perceived Obstacles to the Establishment of the ASEAN Community

\begin{tabular}{|c|c|c|c|c|c|}
\hline Ranks & Obstacles & $\begin{array}{l}\text { Malaysian } \\
\text { Respondents }\end{array}$ & $\begin{array}{l}\text { Indonesian } \\
\text { Respondents }\end{array}$ & $\begin{array}{l}\text { Singaporean } \\
\text { Respondents }\end{array}$ & $\begin{array}{l}\text { The three } \\
\text { countries }\end{array}$ \\
\hline 1 & $\begin{array}{l}\text { Low level of education \& unequally } \\
\text { access and distribution of educational opportunities }\end{array}$ & $\begin{array}{l}\text { Definitely: } 44 \% \\
\text { Possibly: } 47 \% \\
\text { Total } 91 \%\end{array}$ & $\begin{array}{l}\text { Definitely: } 52 \% \\
\text { Possibly: } 40 \% \\
\text { Total. } 92 \%\end{array}$ & $\begin{array}{l}\text { Definitely: } 46 \% \\
\text { Possibly: } 46 \% \\
\text { Total } 92 \%\end{array}$ & $\begin{array}{l}\text { Definitely: } 47 \% \\
\text { Possibly: } 44 \% \\
\text { Total. } 92 \%\end{array}$ \\
\hline 2 & Lack of competitiveness in economy & $\begin{array}{l}\text { Definitely: } 27 \% \\
\text { Possibly: } 63 \% \\
\text { Total: } 90 \%\end{array}$ & $\begin{array}{l}\text { Definitely: } 31 \% \\
\text { Possibly: } 54 \% \\
\text { Total: } 85 \%\end{array}$ & $\begin{array}{l}\text { Definitely: } 29 \% \\
\text { Possibly: } 61 \% \\
\text { Total: } 90 \%\end{array}$ & $\begin{array}{l}\text { Definitely: } 29 \% \\
\text { Possibly: } 59 \% \\
\text { Total: } 88 \%\end{array}$ \\
\hline 3 & $\begin{array}{l}\text { Dependency on the developed } \\
\text { countries, especially for the financing }\end{array}$ & $\begin{array}{l}\text { Definitely: } 42 \% \\
\text { Possibly: } 48 \% \\
\text { Total: } 90 \%\end{array}$ & $\begin{array}{l}\text { Definitely: } 40 \% \\
\text { Possibly: } 44 \% \\
\text { Total: } 84 \%\end{array}$ & $\begin{array}{l}\text { Definitely: } 34 \% \\
\text { Possibly: } 54 \% \\
\text { Total: } 88 \%\end{array}$ & $\begin{array}{l}\text { Definitely: } 39 \% \\
\text { Possibly: } 49 \% \\
\text { Total: } 88 \%\end{array}$ \\
\hline 4 & $\begin{array}{l}\text { Socio-economic disparity and wide income gap } \\
\text { between member countries }\end{array}$ & $\begin{array}{l}\text { Definitely: } 37 \% \\
\text { Possibly: } 52 \% \\
\text { Total: } 89 \%\end{array}$ & $\begin{array}{l}\text { Definitely: } 37 \% \\
\text { Possibly: } 44 \% \\
\text { Total: } 80 \%\end{array}$ & $\begin{array}{l}\text { Definitely: } 35 \% \\
\text { Possibly: } 58 \% \\
\text { Total: } 92 \%\end{array}$ & $\begin{array}{l}\text { Definitely: } 36 \% \\
\text { Possibly: } 51 \% \\
\text { Total: } 87 \%\end{array}$ \\
\hline 5 & Differences in legal and political systems & $\begin{array}{l}\text { Definitely: } 35 \% \\
\text { Possibly: } 52 \% \\
\text { Total: } 87 \%\end{array}$ & $\begin{array}{l}\text { Definitely: } 36 \% \\
\text { Possibly: } 44 \% \\
\text { Total: } 80 \%\end{array}$ & $\begin{array}{l}\text { Definitely: } 50 \% \\
\text { Possibly: } 45 \% \\
\text { Total: } 96 \%\end{array}$ & $\begin{array}{l}\text { Definitely: } 40 \% \\
\text { Possibly: } 47 \% \\
\text { Total: } 87 \%\end{array}$ \\
\hline 6 & Limitation of mastery and creation of technology & $\begin{array}{l}\text { Definitely: } 43 \% \\
\text { Possibly: } 46 \% \\
\text { Total: } 89 \%\end{array}$ & $\begin{array}{l}\text { Definitely: } 47 \% \\
\text { Possibly: } 38 \% \\
\text { Total: } 84 \%\end{array}$ & $\begin{array}{l}\text { Definitely: } 33 \% \\
\text { Possibly: } 54 \% \\
\text { Total: } 86 \%\end{array}$ & $\begin{array}{l}\text { Definitely: } 41 \% \\
\text { Possibly: } 46 \% \\
\text { Total: } 87 \%\end{array}$ \\
\hline 7 & High levels of poverty in many member countries & $\begin{array}{l}\text { Definitely: } 31 \% \\
\text { Possibly: } 44 \% \\
\text { Total: } 75 \%\end{array}$ & $\begin{array}{l}\text { Definitely: } 32 \% \\
\text { Possibly: } 38 \% \\
\text { Total: } 70 \%\end{array}$ & $\begin{array}{l}\text { Definitely: } 29 \% \\
\text { Possibly: } 57 \% \\
\text { Total: } 87 \%\end{array}$ & $\begin{array}{l}\text { Definitely: } 31 \% \\
\text { Possibly: } 46 \% \\
\text { Total: } 77 \%\end{array}$ \\
\hline 8 & Internal conflicts, terrorism and insurgency in the region. & $\begin{array}{l}\text { Definitely: } 33 \% \\
\text { Possibly: } 52 \% \\
\text { Total: } 85 \%\end{array}$ & $\begin{array}{l}\text { Definitely: } 19 \% \\
\text { Possibly: } 42 \% \\
\text { Total: } 61 \%\end{array}$ & $\begin{array}{l}\text { Definitely: } 36 \% \\
\text { Possibly: } 49 \% \\
\text { Total: } 85 \%\end{array}$ & $\begin{array}{l}\text { Definitely: } 29 \% \\
\text { Possibly: } 48 \% \\
\text { Total: } 77 \%\end{array}$ \\
\hline 9 & ASEAN economy is dominated by the ethnic Chinese group & $\begin{array}{l}\text { Definitely: } 22 \% \\
\text { Possibly: } 53 \% \\
\text { Total: } 75 \%\end{array}$ & $\begin{array}{l}\text { Definitely: } 22 \% \\
\text { Possibly: } 39 \% \\
\text { Total: } 61 \%\end{array}$ & $\begin{array}{l}\text { Definitely: } 14 \% \\
\text { Possibly: } 44 \% \\
\text { Total: } 58 \%\end{array}$ & $\begin{array}{l}\text { Definitely: } 19 \% \\
\text { Possibly: } 45 \% \\
\text { Total: } 64 \%\end{array}$ \\
\hline 10 & $\begin{array}{l}\text { Ethnics and religious pluralism make it } \\
\text { difficult for the region to integrate }\end{array}$ & $\begin{array}{l}\text { Definitely: } 22 \% \\
\text { Possibly: } 44 \% \\
\text { Total: } 66 \%\end{array}$ & $\begin{array}{l}\text { Definitely: } 12 \% \\
\text { Possibly: } 27 \% \\
\text { Total: } 39 \%\end{array}$ & $\begin{array}{l}\text { Definitely: } 36 \% \\
\text { Possibly: } 39 \% \\
\text { Total: } 75 \%\end{array}$ & $\begin{array}{l}\text { Definitely: } 23 \% \\
\text { Possibly: } 37 \% \\
\text { Total: } 60 \%\end{array}$ \\
\hline
\end{tabular}

The average years of schooling in Cambodia is 5.8 years, Vietnam-5.5 years, Loas- 4.6 years and 4.0 years in Myanmar Human Development Report, 2010 In terms of education level of adults, in general only $47.27 \%$ of the adult population in the region have attended secondary education-out of which Vietnam and Cambodia registered the lowest with 31.22 and $25.44 \%$ respectively. Similarly, tertiary education has not been accesible for many people in the region. Some countries have registered higher figures compared to lesser developed countries-for example in Singapore and the Philippines more than $24 \%$ of the people had attended tertiary school, as compared to only $8.39 \%$ in Indonesia, $4.96 \%$ in Vietnam and even $1.40 \%$ in Cambodia Education Statistics, 2010. In this region, tertiary education is still a luxury that many could not afford. Understanding 'regional integration' involves some level of abstraction and would require some level of intelligence to decipher the conceptions. As such, the lack of education may hinder a majority the people in the region from grasping the benefit of integration.

Lack of competitiveness in ASEAN economies: The 'lack of competitiveness in the economies of most ASEAN countries' has scored second highest ranking, with some $90 \%$ of Malaysians, $85 \%$ of Indonesians and $90 \%$ of Singaporeans agreeing that this factor may pose an obstacle for the acheivement of regional integration. ASEAN countries are at different levels of economic competitiveness. The World Economic Forum's 'global competitiveness index', which compares 121 countries in the world Global Competitiveness Report, 20102011, only five out of the ten ASEAN countries had performed well in this ranking-namely Singapore in the 3rd world rank, Malaysia in the 26th, Brunei Darussalam in the 28th, Thailand in the 38th and Indonesia in the 44th world rank. Other ASEAN countries were ranked more than 50-Vietnam was at 59th position, the Philippines at 85th position and Cambodia was at 109 th position. As such, the disparity in the levels of development among ASEAN countries and the level of competitiveness of their economies may hamper regional integration initiative, especially when different member states aspire for different benefits. Shortage of skilled labour, low quality and product standards, undeveloped consumer markets, inadequate physical and institutional infrastructure and inadequate intellectual property rights protection pose serious challenges in some ASEAN countries.

Dependency on the developed countries: 'Dependency on the developed countries' received the third highest agreement among respondents as an obstacle for regional integration. Some $90 \%$ of Malaysians, $84 \%$ of Indonesians and $88 \%$ of Singaporeans agree that dependency on developed countries, especially for financing the development and business activities will hamper regional integration 
ambition. The figures from World Development Indicators and Global Development Finance showed that except Brunei Darussalam and Singapore, other ASEAN countries depended heavily on foreign sources for financing-only Singapore and Brunei do not possess external long term debts. Five out of ten ASEAN countries relied heavily on foreign financing for development and business (WB, 2010). The long-term external debt stocks of Indonesia exceeded USD 124 billion in 2008, the Philippines US\$ 57 billion, Malaysia USD 43 billion, Thailand USD 40 billion and Vietnam USD 22 billion. The condition of the three least developed countries of the region (Cambodia, Laos and Myanmar) was even worse as their long-term debts exceeded their domestic credit provided by the banking sector (WB, 2010). As such, it is feared that over dependency of external economic and financial assistance will pose major challenges to regional integration initiatives ASEAN Economic Community Blueprint, 2007.

Socio-economic disparity: 'Low levels of socioeconomic progress and the wide gap between the countries' received the fourth highest agreement among respondents -with some $89 \%$ Malaysians, $80 \%$ Indonesians and $92 \%$ Singaporeans agree that socioeconomic disparity is an obstacle to ASEAN integration. Except for Singapore and Brunei, other ASEAN countries were still in the lower-medium levels of economy and there were wide gaps between the less devoloped and more developed ASEAN countries. The disparity in terms of socio-economic status was noticeable between the more developed members and the less developed countries. For example, the UNDP's Human Development Index (HDI) for the year 2008, 2009 and 2010 had consistently placed most ASEAN countries in the medium level of HDI. With the exception of Singapore, Brunei and Malaysia, which were placed in very high and high HDI categories, the other ASEAN countries were positioned in the medium HDI, with Myanmar in the low HDI. In terms of income per-capita, there was a clear gap in income between the top three HDI ASEAN countries and the rest- for example in 2008 the per-capita Gross National Income (GNI) for Singaporean and Bruneian were more than US\$ 48,000, a vast different from US\$2,995 in Vietnam, US\$ 2,321 in Lao PDR, US\$ 2,172 in Cambodia and US\$ 1,596 in Myanmar Human Development Report, 2010. However, the disparities in levels of economic development were much more pronounced than the disparities in levels of human development.
Differences in legal and the political systems: Differences in the legal (including the degree of law enforcement) and political systems (including the degree of democratic practices) received the fifth highest agreement among respondents-with $87 \%$ of Malaysians, $80 \%$ of Indonesians and $96 \%$ of Singaporeans agree that the differences in the legal and political systems may hamper ASEAN integration. Apart from Thailand, all other countries in Southeast Asia were former colonies of one or several Western powers in their recent history. With colonialism, Western systems of administration and governance were introduced in the colonies. Since there were several colonial powers competing for influence in this region, the systems that were eventually adopted by the Southeast Asian countries also differed during postcolonial period. For example the legal system in Malaysia has an Anglo-Saxon origin and the Indonesia legal system originated from the Dutch. As such, the differences in legal traditions will make it difficult to harmonize the legislations of the various countries in the region. Attempt towards this direction may even stir up sovereignty issues among ASEAN members. Similarly, political systems in the region are also varied and deeply entrenched in Western colonialism. Many ASEAN countries have experienced long and sometimes violent struggle for freedom, while others secured their independence through regional formationsuch as Singapore, which obtained independence through the formation of Malaysia. Due to different origins and history, the political systems in these countries are rather varied-from limited democracies to military juntas. As such, it would be difficult to harmonize the heterogenous political systems to embrace regional integration, or at least to embrace a set of common principles (Severino et al., 2010; Roberts, 2002; 2004; Collins, 2008; Moorthy et al., 2011).

Limitation of mastery and creation of technology: The limitation of mastery and creation of technology received the sixth highest agreement among respondents-with $89 \%$ of Malaysians, $84 \%$ of Indonesians and $86 \%$ of Singaporeans agree that limitation in technology is an obstacle to ASEAN integration. Other than Singapore, many countries in the region are still backward in technology. In terms of knowledge acquisition and access to technology, there is a clear disparity between countries in the region. For example the diffusion of phone lines and internet technology are still very low in CLMV countries- in 2008 in Cambodia, Lao PDR and Myanmar less than $35 \%$ of the people had access to telephone services and less than 9\% used the internet Human Development Report, 2010. In terms of export of high-technology 
products (as the percentage of total exports), in 2008, only Singapore, the Philippines and Malaysia registered more than $30 \%$ export of such products. The high figure is because the high-tech industries were more developed in these countries as a result of foreign investment and supportive government policies. Whereas, Indonesia and Vietnam registered hightechnology exports of less than $6 \%$ of the total exports, while the Cambodian, Laotian and Burmese economies registered below 1\% (UN, 2008; 2010). While the diffusion and mastery of technology in the region have been weak, the technology creation was even weaker. For example, in the last 10 years, in terms of patents granted to residents annually (per million people), only Singapore tops the chart in this region with 140 patents. Indonesia and Vietnam registered only one patent per million people and none in Brunei Darussalam, Cambodia, Lao PDR and Myanmar. In addition, for the receipts of royalties and license fees (US\$) per person annually in the last 10 years, again Singapore tops the rank with USD 26.60. The other ASEAN economies fared quite badly with Malaysia (region's second best) faring at USD 1.67 per person, while the other eight ASEAN countries were below USD1 or even zero (UN, 2009).

Poverty in the region: Poverty ranks number seven in the list of possible obstacles for the formation of the ASEAN community. The opinion survey shows that $75 \%$ of Malaysians, $70 \%$ of Indonesians and $87 \%$ of Singaporeans agree that poverty is an obstacle to ASEAN integration. With the exception of Singapore and Brunei, in all other ASEAN countries there were certain level of poverty in their society-marginal in some countries and more adverse in others. Income poverty has been used widely as an reliable indicator. In ASEAN, whether measured by the national poverty line or the international standards of USD1.25 daily income, some $21.5 \%$ of the regional populace were under the poverty line in 2008. Poverty even exceeded $25 \%$ in five ASEAN countries (Laos 33.5\%; the Philippines 32.90\%; Myanmar 32\%; Cambodia $30.14 \%$ and Vietnam 28.90\%). However, if the international standard of USD 2 daily income is used, the number of poor population jumped into $42.37 \%$ of the whole population in the region. Based on $\$ 2$ a day, the poverty level in five out of ten ASEAN countries exceeded the world and the regional average-Lao PDR registered 76.85\%, Indonesia 59.99\%, Cambodia 57.83\%, Vietnam $48.42 \%$ and the Philippines $45.04 \%$ (WB, 2010). It is argued that the disparity in the poverty levels among ASEAN countires would make it difficult for a meaningful regional integration to take place.
Internal conflicts, terrorism and insurgency: Internal conflicts, terrorism and insurgency in ASEAN countries have been cited as one of the reasons that may hamper ASEAN regional integration. This factor is ranked at number eight out of the list of ten possible obstacles for regional integration. The survey showed that $85 \%$ of Malaysians, $85 \%$ of Singaporean respondents and $61 \%$ of Indonesians consider the issue to be a possible obstacle for establishing the ASEAN Community. Violent conflicts as a result of internal problems, communal strifes, ethnic conflicts, terorrist acts and insurgent activities have proliferated in the region in the past two decades. All countries in the region, perhaps with the exception of Singapore and Brunei have experienced some level of violent conflict situation. According to the Conflict Barometer 2009, there were 30 internal conflicts in the region in that year Conflict Barometer, 2009. Among those were conflicts that involved Muslim extremists in some parts of Indonesia, Southern Thailand, Southern Philippines and Myanmar. These complicated conflicts involved systemic ideology issue of primordialism (nationalism and religious issues) and secessionism which was almost impossible to resolve. Unresolved border disputes, ethno-religious conflicts and secessionist activities in the archipelago may cause serious issues to the regional integration initiative.

\section{CONCLUSION}

The public opinion survey revealed that despite the euphoria of the policy makers regarding the ASEAN Community, the people the three countries have indicated that this initiative will face numerous challenges and obstacles. The high agreements on eigth out of ten obstacles strongly suggests that people in three countries are less likely to support this initaitive. ASEAN's elitist approach and the lack of consideration for public opinion has rendered its regional integration policy unpopular among its people. ASEAN should engage in serious initiative to explain this idea and solicit feedback for the populace.

\section{REFERENCES}

Chong, T., 2008. Globalization and Its Counter-forces in Southeast Asia. 1st Edn., Institute of Southeast Asian Studies, Singapore, ISBN-10: 9812304886, pp: 416.

Collins, A., 2008. A people-oriented ASEAN: A door ajar or closed for civil society organizations? Contemporary Southeast Asia. 
Moorthy, R., N. Lyndon, E.A. Choy, S. Selvadurai and K.A. Talib, 2011. Ethnicity and ethnic perception of indian. J. Soc. Sci., 7: 590-596, DOI: 10.3844/jssp.2011.590.596

Roberts, D., 2002. Political Transition and Elite Discourse in Cambodia, 1991-99. J. Communist Stud. Transition Politics, 18: 101-118.

Roberts, D., 2004. Democratization, elite transition and violence in cambodia, 1991-1999. Critical Asian Stud., $\quad 34$ : 520-38. $10.1080 / 1467271022000035910$

Severino, R., E. Thomson and M. Hong, 2010. Southeast Asia in a New Era: Ten Countries, One Region in ASEAN. 1st Edn., ISEAS, Singapore, ISBN-10: 9812309578, pp: 281.
UN, 2008. The United Nations Today. 1st Edn., United Nations Publications, New York, ISBN-10: 9211011604, pp: 369.

UN, 2010. World Population Prospects: The 2008 Revision. 1st Edn., United Nations Publications, New York, ISBN-10: 9211514649, pp: 940.

WB, 2010. World Development Indicators 2010. 1st Edn., World Bank, Washington, ISBN-10: 0821382322, pp: 488. 